\title{
Lack of benefit from low dose computed tomography in screening for lung cancer - comment on paper by Huang K-L et al.
}

\author{
Don Benjamin (D
}

\begin{abstract}
The article by Huang K-L et al. Effects of low-dose computed tomography (LDCT) screening on lung cancer contains a conclusion that is not consistent with the data presented. With reference to the National Lung Screening Trial (NLST) there are several flaws in the methodology overlooked. Also there is no significant reduction in deaths from all causes following the screening. Therefore any claim that the LDCT screening is superior to usual care is invalid.
\end{abstract}

Keywords: Lung cancer screening, Low dose computed tomography, Methodology

\section{Main text}

You recently published a paper by Huang K-L et al. entitled "Effects of low-dose computed tomography on lung cancer screening: a systematic review, meta-analysis, and trial sequential analysis" [1]. In that paper the authors state in their Conclusion that "LDCT screening has shown statistically significant mortality benefits in highquality trials". In the abstract they further state that "LDCT screening is superiority over usual care in lung cancer survival."

Yet in the Section "Benefits and adverse outcomes" they state "On the contrary, LDCT screening demonstrated no statistically significant difference in all-cause mortality (RR 0.95, 95\% CI 0.90-1.00).

The authors need to explain how a screening technique that produces no statistically significant difference in all-cause mortality between LDCT screening and usual care can be superior to usual care.

This comment refers to the article available at https://doi.org/10.1186/ s12890-019-0883-X.

Correspondence: don.benjamin@bigpond.com

Cancer Information \& Support Society, 6/56 Chandos St, St Leonards, NSW 2065, Australia
The authors also assess the risk for the NLST trial as being Good (Green +) on all criteria, including Methodology.

\section{Potential flaws in methodology}

In fact the NLST trial had several methodological flaws related to the randomisation process overlooked by the authors of the paper:

1. The NLST trial compared LDCT screening of high risk smokers with Chest X-ray (CXR) screening and assumed that Chest $\mathrm{X}$-ray screening produced the same outcome as usual care [2], as suggested in the Prostate, Lung, Colorectal and Ovarian (PLCO) Trial [3], despite earlier trials showing it resulted in an increase in all-cause mortality [4].

2. Anticipating the shortcoming in 1 above, the authors of the NLST trial ensured that the PLCO trial had, in addition to comparing average risk smokers, selected high risk smokers who were offered Chest X-ray screening for comparison with high risk smokers offered usual care - to validate the assumption referred to in 1 . Yet this selection of high risk smokers was done after randomisation, so

(c) The Author(s). 2020 Open Access This article is licensed under a Creative Commons Attribution 4.0 International License, which permits use, sharing, adaptation, distribution and reproduction in any medium or format, as long as you give appropriate credit to the original author(s) and the source, provide a link to the Creative Commons licence, and indicate if changes were made. The images or other third party material in this article are included in the article's Creative Commons licence, unless indicated otherwise in a credit line to the material. If material is not included in the article's Creative Commons licence and your intended use is not permitted by statutory regulation or exceeds the permitted use, you will need to obtain permission directly from the copyright holder. To view a copy of this licence, visit http://creativecommons.org/licenses/by/4.0/ The Creative Commons Public Domain Dedication waiver (http://creativecommons.org/publicdomain/zero/1.0/) applies to the data made available in this article, unless otherwise stated in a credit line to the data. 
the comparison of deaths of high risk smokers after Chest X-ray screening with deaths of those receiving usual care was invalid. In addition the PLCO trial published only lung cancer deaths for the NLST-eligible high risk smokers, not deaths from all causes. This means the assumption in Point 1, that Chest X-ray screening of high risk smokers produced the same outcome as usual care in terms of all-cause mortality was invalid;

\section{Other irregularities}

Reich and Kim observed that the distribution of deaths over time from the NLST-eligible groups selected from the PLCO trial showed irregularities, suggesting that there were some reporting errors in the PLCO trial. They also observed that there were no extra tumours found by the screening in the NLST-eligible groups selected from the PLCO trial [5], casting further doubt on this selection process, suggesting another flaw in the methodology. (The PLCO trial identified less than 5\% more tumours by screening compared with about $20 \%$ more in previous chest X-ray trials.)

The above potential flaws and irregularities suggest that a 'Red -' should be applied to the Randomization process, the Missing outcome data and the Overall risk rather than a 'Green +'. On this basis a lower weighting should be applied to the NLST trial for the purposes of the meta-analysis.

The main shortcoming of the current meta-analysis, like that of many other randomised controlled trials (RCTs) is that the authors ignore the most important outcome, All-cause Mortality, and focus on the Deaths from Lung cancer. If there is no reduction in overall deaths following the screening, it is not valid to claim that LDCT screening is superior to usual care.

As pointed out by Black WC et al., All-cause Mortality in Randomized Trials of Cancer Screening, both trials of Chest X-Ray screening they reported on in 2002 showed an increase in all-cause mortality following Chest X-Ray screening that they attributed to the harm caused by post-screening treatments of higher risk smokers. They pointed out that as "disease-specific mortality may miss important harms (or benefits) of cancer screening because of misclassification in the cause of death, this end point should only be interpreted in conjunction with allcause mortality. In particular, a reduction in diseasespecific mortality should not be cited as strong evidence of efficacy when the all-cause mortality is the same or higher in the screened group" [4].

\section{Other issues}

The NLST trial reported major complication rates following invasive procedures for the LDCT and CXR groups. The risk was higher among persons who underwent LDCT compared with Chest X-ray screening (4.1 vs 3.2 per 10,000 screened). The earlier CXR screening trials had shown an increase in deaths among those offered screening compared to those not offered screening (usual care). This is strong evidence in support of the suggestion that some of the reduction in deaths from lung cancer following LDCT screening could have been due to deaths from other causes resulting from the treatment that, as suggested by Black et al. above, should have been classified as deaths from lung cancer. There should therefore be strong reservations made about any claim that the LDCT screening was superior to usual care.

From the above, one possible explanation for the apparently positive result claimed in the NLST trial is that the Chest X-ray screening had in fact increased the number of deaths among those offered screening, as had been observed in previous trials [4]; the LDCT screening had reduced the number of deaths by a similar amount compared to Chest X-ray screening; the net result being that there was no significant reduction in overall deaths (as observed). Some of the reduction in lung cancer deaths could have been due to the methodological flaws outlined above.

Finally, the NLST trial is the only large trial to claim benefits for cancer screening, which would make lung cancer screening the only type of cancer screening to produce significant benefits. Randomised trials of breast, bowel, prostate and ovarian cancer screening have not produced significant reductions in all-cause mortality [6] and thyroid cancer screening has largely been discontinued due to much evidence suggesting no benefits but significant harm from overdiagnosis and overtreatment.

\section{Abbreviations \\ CXR: Chest X-ray; LDCT: Low dose computed tomography; NLST: National Lung Screening Trial; PLCO: Prostate, Lung, Colorectal and Ovarian (Trial);} RCT: Randomised Controlled Trial; RR: Relative Risk; Cl: Confidence Interval

\section{Acknowledgements}

Not applicable.

\section{Author's contributions}

The above letter is completely the work of the author DB. The author(s) read and approved the final manuscript.

\section{Authors' information}

Don Benjamin has previously published papers on the subject of evaluating the efficacy of cancer surgery and cancer screening.

\section{Funding}

The research giving rise to the above letter is being funded by the author's employer The Cancer Information \& Support Society Incorporated. based on a recommendation from the Society's Research Director (the author). This research is part of an ongoing four-year project that has identified a flaw in claims of benefits from lung cancer and other cancer screening. The article by Huang et al. [1] had supported the claim that LDCT lung cancer screening produces benefits, contrary to the Society's research findings. The current letter commenting on this article therefore uses data produced from the original research and funds for writing this letter come from the same project. 
Availability of data and materials

Not applicable.

Ethics approval and consent to participate

Not applicable.

\section{Consent for publication}

Not applicable.

\section{Competing interests}

The author declares that he has no competing interests.

Received: 17 October 2019 Accepted: 31 July 2020

Published online: 26 August 2020

\section{References}

1. Huang K-L, et al. Effects of low-dose computed tomography on lung cancer screening: a systematic review, meta-analysis, and trial sequential analysis. BMC Pulm Med. 2019;19:126.

2. National Lung Screening Trial Research Team. Reduced lung-cancer mortality with low-dose computed tomographic screening. N Engl J Med. 2011;365(5):395-409. https://doi.org/10.1056/NEJMoa1102873.

3. Oken MM, for the PLCO Project Team, et al. Screening by chest radiograph and lung cancer mortality. The Prostate, Lung, Colorectal, and Ovarian (PLCO) Randomized Trial. JAMA. 2011;306(17):1865-73. https://doi.org/10. 1001/jama.2011.1591.

4. Black W, Haggerstrom D, Welch HG. All-cause mortality in randomized trials of cancer screening. J Natl Cancer Inst. 2002;94(3):167-73 Author's response to discussion: 5 June 2002; 94 (11): 865-6.

5. Reich JM, Kim JS. The National Lung Screening Trial premise of null and chest radiography equivalence is open to question. Am J Roentgenol. 2015; 205:278-9.

6. Benjamin DJ. The efficacy of surgical treatment of cancer - 20 years later. Med Hypotheses. 2014;82(4):412-20.

\section{Publisher's Note}

Springer Nature remains neutral with regard to jurisdictional claims in published maps and institutional affiliations.

\section{Ready to submit your research? Choose BMC and benefit from:}

- fast, convenient online submission

- thorough peer review by experienced researchers in your field

- rapid publication on acceptance

- support for research data, including large and complex data types

- gold Open Access which fosters wider collaboration and increased citations

- maximum visibility for your research: over $100 \mathrm{M}$ website views per year

At $\mathrm{BMC}$, research is always in progress.

Learn more biomedcentral.com/submissions 